\section{Teaching Writing-With or Without Metacognition?: An Exploratory Study of 11- to 12-Year-Old Students Writing A Book Review}

\author{
Stéphane Colognesi ${ }^{\mathrm{a},{ }^{\star}}$, Clémence Piret ${ }^{\mathrm{b}}$, Simon Demorsy ${ }^{\mathrm{c}}$ \\ Elise Barbier ${ }^{\mathrm{d}}$
}

\begin{tabular}{ll}
\hline Received: & 18 March 2020 \\
Revised: $\quad 5$ June 2020 \\
Accepted: $\quad 20$ June 2020 \\
ISSN: $1307-9298$ \\
Copyright @ IEJEE \\
www.iejee.com
\end{tabular}

DOI: 10.26822/iejee.2020562136

\begin{abstract}
In this contribution, we attempt to answer two research questions: (1) What effects do metacognitive questions have on students' writing skills? and (2) How do students respond to metacognitive questions? To answer these questions, we conducted an experiment with 43 students who were 11 to 12 years old. They were engaged in writing in a particular genre: book reviews. These pupils belonged to two classes at the same school, and for three weeks they experienced an instructional system combining identified principles of effective writing instruction, taught by the same teacher. They were required to rewrite their text several times, with the only difference being that in one group, metacognitive questions were introduced before, during, and after writing, unlike in the other class. A total of 172 written productions were analyzed under both conditions. Student responses in the metacognition condition were also analyzed. Our results show that students in both conditions made significant progress. But in the metacognitive condition, students made more significant progress.
\end{abstract}

Keywords: Metacognition, Metacognitive Mediation, Writing, Primary School

\section{Introduction}

Since the 1980s, there has been real interest in the issue of metacognition. Since that point, this field of research has undergone great development, occupying a major place in the field of educational psychology (Desoete \& Ozsoy, 2009; Doudin, Martin, \& Albanese, 1999; Veenman, 2012). Metacognition is an essential prerequisite for self-regulated learning (Dörr \& Perels, 2019). Metacognition-related instruction is recognized as an effective teaching practice (Hattie, 2009; Ko, Sammons, \& Bakkum, 2014). Indeed, the literature has identified the impact of metacognitive skills on academic success (Sternberg, 1998). The use of metacognition can improve academic achievement. In particular, this has been demonstrated in the area of mathematics learning and problem solving (Focant, Grégoire, \& Desoete, 2006; Desoete, 2017; Hanin \& Van Nieuwenhoven, 2018; Özsoy, 2011; Özsoy \& Ataman, 2009). The use of metacognition encourages students to reflect on what they know, to understand the reasoning they use to solve tasks, and thus to construct new knowledge (Veenman, 2012; Zimmerman, Bonner, \& Kovach, 2000). Engagement in metacognition also develops a greater sense of self-efficacy (Colognesi, Hanin, Still, \& Van Nienwenhoven, 2019). This is due to the fact that learners can take a look at their work, at the development of their skills, and at their understanding of school subjects. This leads to an awareness of progress and of how one learns, and a better relationship with knowledge (Wilson \& Bai, 2010).

Several studies have examined the links between metacognition and improved writing quality. Some work has shown that metacognition encompasses the processes of planning, writing, monitoring and evaluation before, during and after writing (Andrade, 1999; Schraw, 1998; Zimmerman, 1995). This is not surprising, since writing is a complex problem-solving activity (Hayes \& Flower, 1980), and therefore involves a metacognitive process (Zimmerman \& Kitsantas, 2007). Meta-analyses such as those by Koster, Tribuschinina, de Jong and van den Bergh (2015) or van Weijen and Janssen (2018) have highlighted that strategy instruction and the development of metacognitive strategies is an effective practice for teaching writing.

Braund and Soleas (2019) explained that "an important direction for metacognitive researchers to explore is to focus on more effective strategies to be implemented in classrooms to promote metacognitive skills" (p. 106). The authors added that " it is crucial that the next generation of teachers have a strong understanding of what metacognition is, and how best to support metacognitive skills in their classrooms" ( $p$. 108). Indeed, in the classroom, few teachers are implementing metacognition-related activities in their practice (Depaepe, DeCorte, \& Verschaffel, 2010, 2015; Vlassis, Mancuso \& Poncelet, 2014). However, the teacher's role is fundamental in such implementation, because "access to metacognitive reasoning depends largely on the way in which the teacher conceives of learning activities" (Doly, 1997).

Thus, how can metacognition-related instruction be involved in the context of teaching writing? At what points can students be involved? What are the effects of this involvement on the development of students' writing skills? How do students respond when they are offered metacognitive mediations related to their writing activity? These are the aspects addressed in this contribution.

\section{Metacognition}

Researchers interested in metacognition have been trying to define this term, which nonetheless harbors a conceptual vagueness. Indeed, Veenman et al. (2006) drew attention to the multitude of notions that exist. He mentioned that "the relation of some specific terms with the overall concept of metacognition is not unequivocally defined" (p. 4). Hacker (1998) held that "metacognition includes both knowledge of one's knowledge, processes, cognitive and affective states,

a,*Corresponding Author: Stéphane Colognesi, Université catholique de Louvain, Faculty of Psychology and Educational Sciences, IPSY: Psychological Sciences Research Institute, Louvain-la-Neuve, Belgium. ORCID : http://orcid.org/0000-0001-5763-5873, E-mail: stephane.colognesi@uclouvain.be Clémence Piret, Haute Ecole Louvain en Hainaut, Chaussée de Binche, Mons, Belgium. E-mail: piretc@helha.be Simon Demorsy, Université catholique de Louvain, Faculty of Psychology and Educational Sciences, IPSY: Psychological Sciences Research Institute, Louvain-laNeuve, Belgium. E-mail: Demorsysimon@hotmail.com

d Elise Barbier, Université catholique de Louvain, Faculty of Psychology and Educational Sciences, IPSY: Psychological Sciences Research Institute, Louvain-laElise Barbier, Université catholique de Louvain, Facu
Neuve, Belgium. E-mail: elise.barbier@uclouvain.be 
and the ability to consciously and deliberately monitor and regulate one's knowledge, process, and cognitive and affective states" (p. 11).

Three facets of metacognition can be distinguished: metacognitive knowledge, metacognitive skills and metacognitive experiences (Desoete \& Ozsoy, 2017; Efklides, 2006, 2008).

Metacognitive knowledge is used to achieve a goal (Focant, 2004; Hanin, 2018; Lester, Garofalo, \& Kroll, 1989). Flavel (1976) stated that it is "a person's declarative knowledge about interactions between a person, the task and the characteristics of the strategy" (p. 19). The author explained that metacognition then refers to an individual's knowledge of his or her own cognitive processes. This metacognitive knowledge is based on both cognitive and metacognitive strategies (what), the way to implement them (how), the type of task in which it is relevant to mobilize them and the most appropriate time to do so (when), and the usefulness of these strategies (why).

Metacognitive experiences are "the judgements and feel ings that an individual has about their learning and thinking" (Braund \& Soleas, 2019, p. 107). They refer to what a person becomes aware of and feels when they encounter a task and process the related information (Efklides, 2008). These may be feelings of self-trust, or feelings of difficulty (Ben-David \& Orion, 2013; Efklides, 2006).

The third dimension, metacognitive skills, is related to procedural knowledge, that is, knowledge of the procedure by which an individual regulates their problem-solving and learning activities (Brown, 1987; Brown \& Deloache, 1978; Veenman 2005). Brown (1987) considered metacognitive skills to be the activities of planning, predicting, steering, guiding and controlling outcomes. Indeed, metacognition leads individuals to reflect on their own actions. They then become aware of the path that led them to the results obtained. They observe their mistakes, discover the reasoning that led their mistakes, and look for appropriate solutions (Veenman et al., 2006, 2012). Noël (1997) specified that once that kind of knowledge has been made conscious, the individual will carry out "behaviors", such as re-reading. These behaviors constitute what she called "regulatory actions", which are the product of metacognition and not "metacognition itself, which is a mental process" (Noël, 1997, p. 21). In the end, self-regulation is the result of metacognition: learners should use metacognitive skills to regulate and control themselves (Houart, 2017; Perfect \& Schwartz, 2002).

Braund and Soleas (2019) explained that "it is imperative that students learn and practice developing all three metacognition components" (p. 107). In class, students can be questioned before, during and after the task. Questioning before should encourage them to direct and plan their actions (Colognesi \& Van Niewenhoven, 2016; Veenman, 2012). Questioning during should require them to explain what they are doing and why they are doing it. Questioning afterwards should get them to evaluate their work and to project themselves doing a similar task. It is then a question of identifying successful strategies for a possible repetition of the task. These metacognitive mediations can take two forms. They can be questions asked by the teacher: metacognitive prompts (Gagnière, 2010), or they can be questions asked by students among themselves: allo-confrontations (Gagnière, 2010).

To activate metacognition, students can be asked questions. These are called metacognitive mediations. These questions may occur before, during or after the tasks. Figure 1 highlights the six types of metacognitive mediation that can take place in the classroom (Colognesi \& Van Nieuwenhoven, 2016).

Prior to the task, students can be asked to engage in metacognitive mediations related to orientation and planning. Orientation involves asking students to identify the goals they want to achieve "according to the requirements of the task" (Gagnière, 2010 , p. 28). Planning consists of analyzing "the information about the task and its requirements, making an inventory of available strategies, planning how to proceed, determining the stages of accomplishment" (Gagnière, 2010, p. 28). That involves a "fair representation of the activity to be accomplished" (Portelance, 1999, p. 45).

During the execution of the task, metacognitive mediations can concern two types of activities: monitoring and verification monitoring. Monitoring requires them to explain the errors they have detected, "the deviations between actions and the initial plan or the appropriate application of planned strategies" (Gagnière, 2010, p. 29). Verification monitoring commits students to talking about their approach, criticizing it, justifying. This allows adjustment decisions to be made if necessary.

After the task has been completed, two types of metacognitive mediation can be used : production evaluation and process evaluation. Production evaluation engages the student in taking stock of the production by questioning whether the objective has been achieved. But they can also identify out the positive and negative aspects, using evaluation criteria. This means having a critical attitude towards what has been produced. Process evaluation asks the student to reflect on the entire process. The student can then identify the strategies used to solve the task. They can also highlight which ones were useful, which ones they would reuse for a future edition of the task.

There are three ways in which information about learners' metacognitive activities can be solicited through questioning. First, in think-aloud protocols (Fox et al., 2011) students can be asked to verbalize aloud about their thought processes. Second, judgments of learning (Mitchum, Kelley, \& Fox, 2016; Nelson \& Dunlosky, 1991) involve asking students to make judgements about their ability to redo a task. It is a self-assessment measure. Third, confidence ratings (Stankow \& Lee, 2008; Yeung \& Summerfield, 2014) involve asking students to

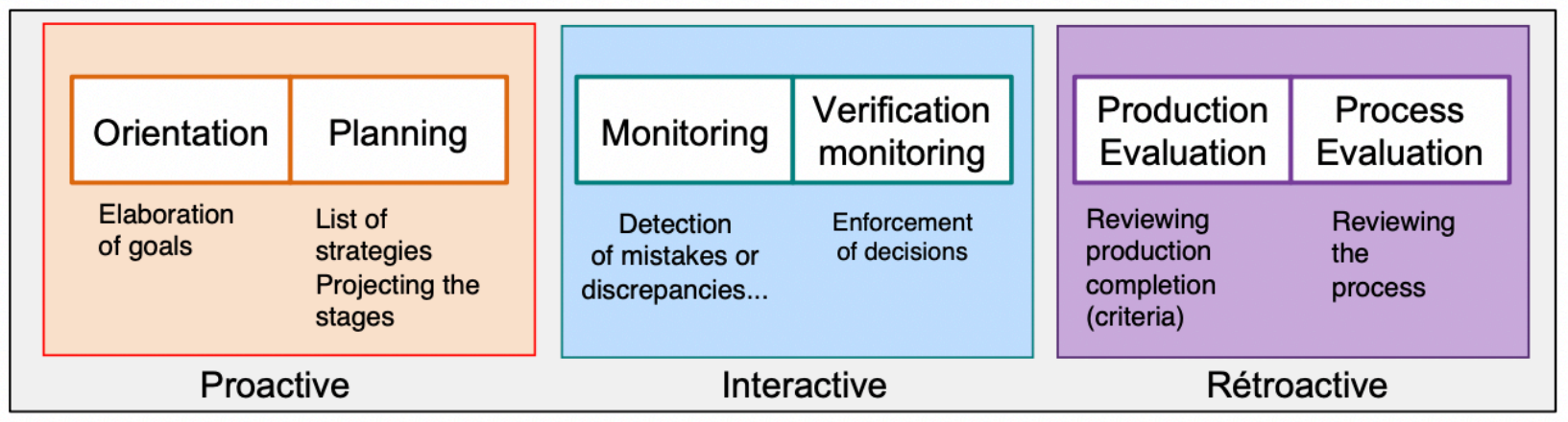

Figure 1. Six types of metacognitive mediation (Colognesi \& Van Nieuwenhoven, 2016) 
position themselves in relation to the task by giving a confidence rating. These three ways can occur before, during and after the task.

\section{Metacognition and writing instruction}

Teaching writing is a complex task that requires support (Hayes \& Flower, 1980; Ramet, 2007). Two recent meta-analyses have highlighted four major factors that determine the effectiveness of writing instruction (Koster et al., 2015; van Weijen \& Janssen, 2018). These are goal setting, peer support, feedback and instruction on writing strategies. The teaching of strategies can be linked to metacognition. Indeed, in some approaches such as the Self-Regulatory Strategy Development (SRSD) model of Harris and Graham (1996), students are taught self-regulation strategies. This is to "manage the writing process, as well as declarative and procedural knowledge about writing" (Koster et al., 2015, p. 256). In this respect, the research has shown that the most successful writers are those who can consciously use self-assessment criteria to check the quality of their writing, especially during revision (Zimmerman \& Risemberg, 1997).

Graham, Harris, and Mason (2005) observed the relationship between metacognitive strategies and writing performance in an experimental study, in which, students were asked about the strategies they used to plan and write their assignments. The results of the study showed that students who explained their method improved in their writing. By studying university students who wrote an argumentative text, Escorcia and Fenouillet (2011) also showed that metacognition is strongly linked to the production of better quality texts. Their study was done on the basis of questionnaires and analysis of the written products. The results showed that the best performing students had more information about the activity and showed a better understanding of their strategies.

Several studies have shown that metacognition has an important effect on learners' writing and thinking skills (Cer, 2019; Kim, 2016; Lu, 2006; Mekala, Shabitha, \& Ponmani, 2016; Yanyan, 2010; Zimmerman \& Bandura, 1994). This work has shown that learners become aware of the strategies they use in writing, identify effective strategies, and adapt accordingly.

In a previous study (Colognesi \& Van Nieuwenhoven, 2016), we asked metacognitive questions of 1610 - to 12 -year-old students at three points during their writing activities. They were asked to write a lost-and-found notice about their childhood teddy bear. Prior to the task, students were asked to express their specific goals and explain how they were going to proceed. While they were writing, the researcher invited them to explain what they were doing (changing, deleting or adding something) and why. After the task, they had to say if they were satisfied with their work, why, and identify the strategies that were used. The result of this study showed that these moments of metacognitive activity brought an awareness of the mechanisms involved in writing. They also supported the development of planning, writing and revision skills. Results of that study has also been shown that the metacognitive mediations thus offered to students lead them to become aware of their progress. In fact, these mediations lead students to make their progress explicit and consistent. Moreover, they highlight the benefits of the learning activities implemented by the teacher or the contributions of peers.

Cer (2019) conducted a study of 44 secondary school students. His objective was to examine the effect of the metacognition on improving learners' writing skills. Students in the experimental group were trained to use writing practices based on the metacognitive strategy. This was not the case for the control group. The study found that students in the "metacognition" condition improved their writing skills. They improved on the following aspects: context, style, language and structures of expression. In addition, the pupils in the experimental group "developed strategies related to what they know and how they know it, as well as why and when they should use pieces of information, with the aid of learning about learning and thinking about thinking" (Cer, 2019, p. 13). However, the author pointed out at the end of his text that his findings suggest that further research should be conducted. He believed that a more full determination of the impact of metacognition on writing skills is needed.

\section{This study}

This study may echo other work that has analyzed the issue. But in many cases, this other work (for example Cer, 2019; Escorcia and Fenouillet, 2011) has been done with students in secondary or higher education. And those studies did not investigate a comprehensive instructional program based on effective literature-based practices for teaching writing. That is our contribution.

In our previous work (Colognesi \& Lucchini, 2018a), we have already sought to show the effects of a training program that combines effective practices for teaching writing identified in recent meta-analyses (Koster et al., 2015; van Weijen \& Janssen, 2018). But we considered these practices all at the same time (teacher input, peer interaction and metacognition). We did not show what metacognition contributes, in addition to the contribution of teacher input and peer interaction. In other words, what impact can the individual student alone have on their own writing process by being metacognitive? How might getting students to respond to metacognitive questions before, during, and after writing improve their writing skills, when this is done as part of an instructional approach that involves the use of effective practices for teaching writing?

To answer this question, we conducted an experiment with 43 students who were 11 to 12 years old. They were engaged in writing in a particular genre: book reviews. These pupils belonged to two classes at the same school, and for three weeks they experienced an instructional system combining identified principles of effective writing instruction (Koster et al., 2015), taught by the same teacher. They were required to rewrite their text several times (Kellogg, 2008), with the only difference being that in one class, metacognitive mediation was introduced before, during, and after learning and writing tasks, unlike in the other class.

There were two research questions:

(1) What effects do metacognitive questions have on students' writing skills?

(2) How do students respond to metacognitive questions?

\section{Method}

\section{Sample}

The sample consisted of 43 pupils, 11-12 years old, from the same school (a public school in the French-speaking community of Belgium), located in a well-off socio-cultural environment. These 43 students are divided into two classes. Students in one class were all in the metacognitive condition and those in the other class were all in the other condition. The matching of condition and class was done by drawing lots. 
The non-metacognitive condition included 20 students: 7 girls and 13 boys. 19 students in this condition were native French speakers and one was of foreign origin (Romanian). The metacognitive condition included 23 students: 13 girls and 10 boys. 21 students in this condition were native French speakers, while two were of foreign origin (Moroccan and Romanian).

To obtain parental consent, a specific request was made to the parents of the two groups in the sample.

In order to ensure that students were at the same level for different elements of writing skill initially, we conducted a pretest. Students had to write a text giving their opinion on their favorite book. Ten elements of writing skills were assessed, the same skills addressed during the instructional program (see Table 1 below; the criteria used to assess these elements are given in Table 3 ). The $t$-test revealed no significant differences between the two conditions. This suggests that the two groups were at a similar level before starting the experiment.

\section{Instructional Program}

The experiment was carried out during the months of January and February, 2018, and lasted four weeks. Students worked for a total of 800 minutes ( 16 periods of 50 minutes each) over 4 weeks.

The "itineraries" method of instruction for writing skills (Colognesi \& Lucchini, 2016a, 2018a) was used. In this method, students produce several written versions of their text. They rewrite their text several times and progress from one ver- sion to the next. Interventions to support them and help them overcome obstacles are provided between these writing efforts. The following occur in alternation: teacher scaffolding (focused on the knowledge necessary for the genre in question) and feedback from peers. In addition, in this method, metacognitive questions are asked of students before, during and after the tasks. Figure 2 provides an overview of the stages the students went through. The same teacher taught in both conditions. He was trained in the method beforehand, and received all the necessary materials. The researchers met with him several times to answer his questions, and a researcher was present in the classroom during the teaching sessions, which helped to ensure fidelity of implementation of the instructional method.

In both conditions, one class period (50 minutes) was spent defining the objectives for students and explain the writing project to them. The instructions were as follows: "You are going to put yourself in the shoes of a comic book critic and share your comic book preferences with the other students. You will be asked to present your favorite comic book and give your opinion. So you're going to have to critique your favorite comic book". The students determined with the teacher the parameters of the writing situation (who is writing, for whom, under what conditions, what, why, etc.).

The students produced five versions of their text. About 50 minutes was spent on writing each time. To help students improve, they received coaching from the teacher and their peers. The teacher delivered instructional scaffolding at three points. The first took place after the first version of the text

Table 1. Descriptive statistics and comparison of initial pre-test scores for elements of writing skills per condition

\begin{tabular}{|c|c|c|c|c|c|c|}
\hline & \multicolumn{2}{|c|}{$\begin{array}{l}\text { non-metacognitive condition } \\
\qquad n=20\end{array}$} & \multicolumn{2}{|c|}{$\begin{array}{l}\text { metacognitive condition } \\
\qquad n=23\end{array}$} & \multirow[t]{2}{*}{$t_{(41)}$} & \multirow[t]{2}{*}{$p$} \\
\hline & $M$ & $S D$ & M & $S D$ & & \\
\hline Communication intention /4 & 3.05 & $(.91)$ & 3.04 & $(.48)$ & -.03 & .515 \\
\hline Idea development /7 & 4.84 & $(1.95)$ & 4.48 & $(1.53)$ & -.66 & .743 \\
\hline Message organization /6 & 4.16 & $(1.25)$ & 4.65 & (.93) & 1.41 & .082 \\
\hline Textual consistency /6 & 2.95 & $(1.54)$ & 2.87 & $(1.36)$ & -.17 & .567 \\
\hline Vocabulary /6 & 3.26 & $(1.66)$ & 3.30 & $(1.14)$ & .09 & .463 \\
\hline Sentence construction /10 & 8.52 & (1.95) & 9.17 & $(1.07)$ & 1.29 & .104 \\
\hline Verbs /10 & 8.71 & $(1.13)$ & 8.15 & $(1.40)$ & -1.43 & .920 \\
\hline Adverbs & 3.26 & $(.32)$ & 3.30 & $(.29)$ & .09 & .463 \\
\hline Spelling /50 & 47 & $(.56)$ & 47.30 & $(.57)$ & .34 & .366 \\
\hline Presentation /8 & 6.15 & (1.01) & 6.22 & (.99) & .19 & .424 \\
\hline
\end{tabular}

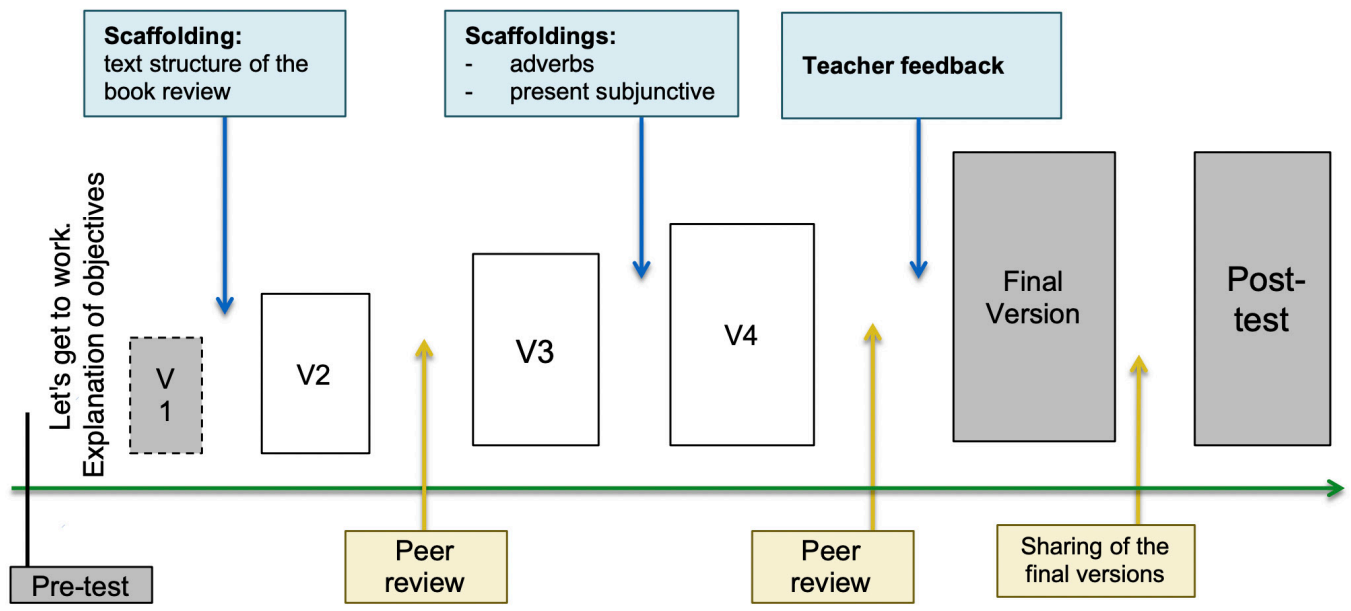

Figure 2. Schematization of the instructional program (see Colognesi \& Lucchini, 2018a) 
had been written (duration of teaching activity : 2 class periods of 50 minutes each). Students compared model texts to isolate the text structure of the book review. The methodology presented by Colognesi and Lucchini (2018b) was used for this instruction. The other two teaching moments took place after writing the third version of the text (4 class periods of 50 minutes each). The students worked on adverbs and on the use of the present subjective. These topics were selected because they play a major role in book reviews.

Twice, in sub-groups of four, students read the texts of another group and gave feedback to their peers. This was done after writing the second and fourth versions of the text (50 minutes each time). See Colognesi and Descehepper (2018) for details on the specific steps and effects of these collaborative review moments. After the second peer feedback event, the teacher also gave feedback. He read the students' texts and annotated them. This included using a code to allow students to correct their own work.

After writing their final version of the book review, students were able to read each other's texts (50 minutes). Finally, two weeks later, the students had to write a new text on their own. This served as a post-test (50 minutes). The instruction was to write a film review. The students had viewed the film the week before.

In the non-metacognitive condition, the students were not asked the questions associated with metacognitive mediations. However, they worked on writing at the same time as in the other class. They simply had more time to write and proofread their text with tools such as the dictionary or conjugation tables.

In the metacognitive condition, students were asked metacognitive mediation questions before, during and after the periods of writing. These were asked not only when they were required to write, but also when they were working with the teacher (on text structure, adverbs and the present subjunctive tense of verbs).

Before and after learning and writing tasks, they had to respond orally to the teacher's questioning. During the writing times, students were invited to pair up for discussions, based on questions written on the blackboard. The metacognitive mediation questions are presented in Table 2. These questions are based on the work of Authors (2016a, 2019).

Table 2. Questions asked of students in the metacognitive condition

\begin{tabular}{|c|c|}
\hline $\begin{array}{l}\text { Before learning and } \\
\text { writing tasks }\end{array}$ & $\begin{array}{l}\text { - Explain your understanding of the task. } \\
\text { - What is your personal goal for this task? } \\
\text { - How will you proceed: what steps do you } \\
\text { think you will take? Where will you start? }\end{array}$ \\
\hline $\begin{array}{l}\text { After learning and } \\
\text { writing tasks }\end{array}$ & $\begin{array}{l}\text { - How did you go about completing the task? } \\
\text { What steps did you go through? } \\
\text { - What did you learn in this activity? } \\
\text { - Are you satisfied with your work? } \\
\text { - If you do the same activity again tomorrow, } \\
\text { what strategies will you use to be more effec- } \\
\text { tive? What are the reasons for this? }\end{array}$ \\
\hline During writing tasks & $\begin{array}{l}\text { - Explain what you've done so far. What steps } \\
\text { have you gone through? } \\
\text { - When you encountered a difficulty, what did } \\
\text { you do? } \\
\text { - And now, how do you think you're going to } \\
\text { continue writing? What are your next steps? }\end{array}$ \\
\hline
\end{tabular}

\section{Methods of data collection and analysis}

To answer our research questions, a mixed-method approach was used (Creswell \& Plano Clark, 2007).

\section{Measuring student progress}

To observe the effects of the metacognitive mediations on students' writing outcomes, we considered three of the six texts produced by the students: the first version of the book review (V1), the last version of the book review (Final Version) and the film review (post-test). In the end, the pre-test and these three products for each student were evaluated, a total of 172 written products. Two experienced teachers did the evaluations. They worked in the same room, each one working separately on a given text. Then they discussed their evaluations, to reach an agreement on the grade to be given for each element. The criteria used for the evaluation of the written products are presented in Table 3. They were previously used in the frameworks of other studies (Authors, 2017, 2020). The different elements of writing skills relating to textual knowledge and know-how were evaluated (Dabène, 1991; Lord, 2009).

A $t$-test analysis was used to compare the mean scores of two groups on the pre-test and post-test. An analysis of variance (repeated measures ANOVA) was applied to the results obtained for $\mathrm{V} 1$, the final version, and the post-test. A Tukey-Kramer post-hoc test was used to compare pairs of means.

Collecting student responses to metacognitive questions. In the metacognitive condition, students' responses to metacognitive questions asked by the teacher (before and after the tasks) were audio recorded. Discussions between students were also recorded. All data were transcribed in full. A content analysis was applied to the collected data. A mixed model was used (L'Ecuyer, 1990). Thus, student responses were coded according to pre-existing and induced categories. The pre-existing categories were the elements of writing skills presented above. As the objective was to understand the progress identified in the statistical analysis, particular attention was paid to those elements of writing skills that have evolved the most. This was done in relation to student responses before, during and after the tasks. The categories that have been induced relate to the students' perception of progress and the tasks they have experienced.

\section{Main Results}

The results are presented according to the two research questions: (1) What effects do metacognitive questions have on students' writing skills? and (2) How do students respond to metacognitive questions?

What effects do metacognitive questions have on students' writing skills?

Regarding the quantitative approach it is worth mentioning that, prior to analysis, checks of the theoretical assumptions underlying analysis of variance were undertaken including normality, homogeneity of variance and independence. The report showed that the assumptions were met.

Table 4 shows the students' results by condition at the three times evaluated: the first version of their comic book review (Time 1), the final version (Time 2) and the post-test (Time 3). As a reminder, the film review (post-test) was produced a few weeks after the experiment.

There are three main aspects to note when reading the results. 
Table 3. Criteria used to evaluate elements of students' writing skills

\begin{tabular}{|c|c|c|}
\hline Element of writing skills & Criteria & Scoring \\
\hline $\begin{array}{l}\text { Adapt writing according to the commu- } \\
\text { nication situation (i.e., communication } \\
\text { intention) /4 }\end{array}$ & $\begin{array}{l}\text { - compliance with the instructions } \\
\text { - awareness of audience }\end{array}$ & $\begin{array}{l}\text { A rating from } 0 \text { to } 3 \text { for the first criterion }(0=\text { no, } \\
1=\text { partial, } 2=\text { yes, } 3=\text { excellent); } 1 \text { point (yes) or } \\
0 \text { (no) for the second criterion }\end{array}$ \\
\hline Idea development /7 & $\begin{array}{l}\text { - quality of content developed } \\
\text { - clarity of ideas presented } \\
\text { - effortless understanding of the whole text }\end{array}$ & $\begin{array}{l}\text { A rating from } 0 \text { to } 3 \text { for the first two criteria; } 1 \\
\text { point (yes) or } 0 \text { (no) for the third criterion } 1\end{array}$ \\
\hline Message organization /7 & $\begin{array}{l}\text { - title } \\
\text { - introduction } \\
\text { - book information } \\
\text { - book summary } \\
\text { - personal view } \\
\text { - conclusion } \\
\text { - uses paragraphs }\end{array}$ & 1 point for each desired characteristic identified \\
\hline Textual consistency /6 & $\begin{array}{l}\text { - paragraph links } \\
\text { - anaphoric network }\end{array}$ & A rating from 0 to 3 for each criterion. \\
\hline Vocabulary /6 & $\begin{array}{l}\text { - rich vocabulary } \\
\text { - book review vocabulary }\end{array}$ & A rating from 0 to 3 for each criterion. \\
\hline Sentence construction /10 & - syntactically and semantically correct sentences & $\begin{array}{l}\text { The ratio of the number of correct sentences to } \\
\text { the total number of sentences. The result has } \\
\text { been transformed on } 10 \text { points. }\end{array}$ \\
\hline Verbs $^{2} / 10$ & - verbs agreement & $\begin{array}{l}\text { The ratio of the number of properly conjugated } \\
\text { verbs to the total number of verbs. The result } \\
\text { has been transformed on } 10 \text { points. }\end{array}$ \\
\hline Adverbs: count & number of adverbs used in the text & Counting \\
\hline Spelling / 50 & - misspelled words & On the first 50 words: 1 point per correct word \\
\hline Presentation of the text $/ 8$ & $\begin{array}{l}\text { - Handwriting } \\
\text { - overall presentation of the document (readability, care) }\end{array}$ & A rating from 0 to 4 for each criterion \\
\hline
\end{tabular}

is awarded if the text is read in one go without having to go back over certain sentences to understand them. 0 is awarded if it is necessary to reread certain parts of the text sev times in order to understand it. ${ }^{2}$ Verbs and adverbs were each the subject of a specific criterion because these were the learning objects that were worked on during the scaffolding.

Table 4. Repeated measures ANOVA results, descriptive statistics for observed elements of writing per condition

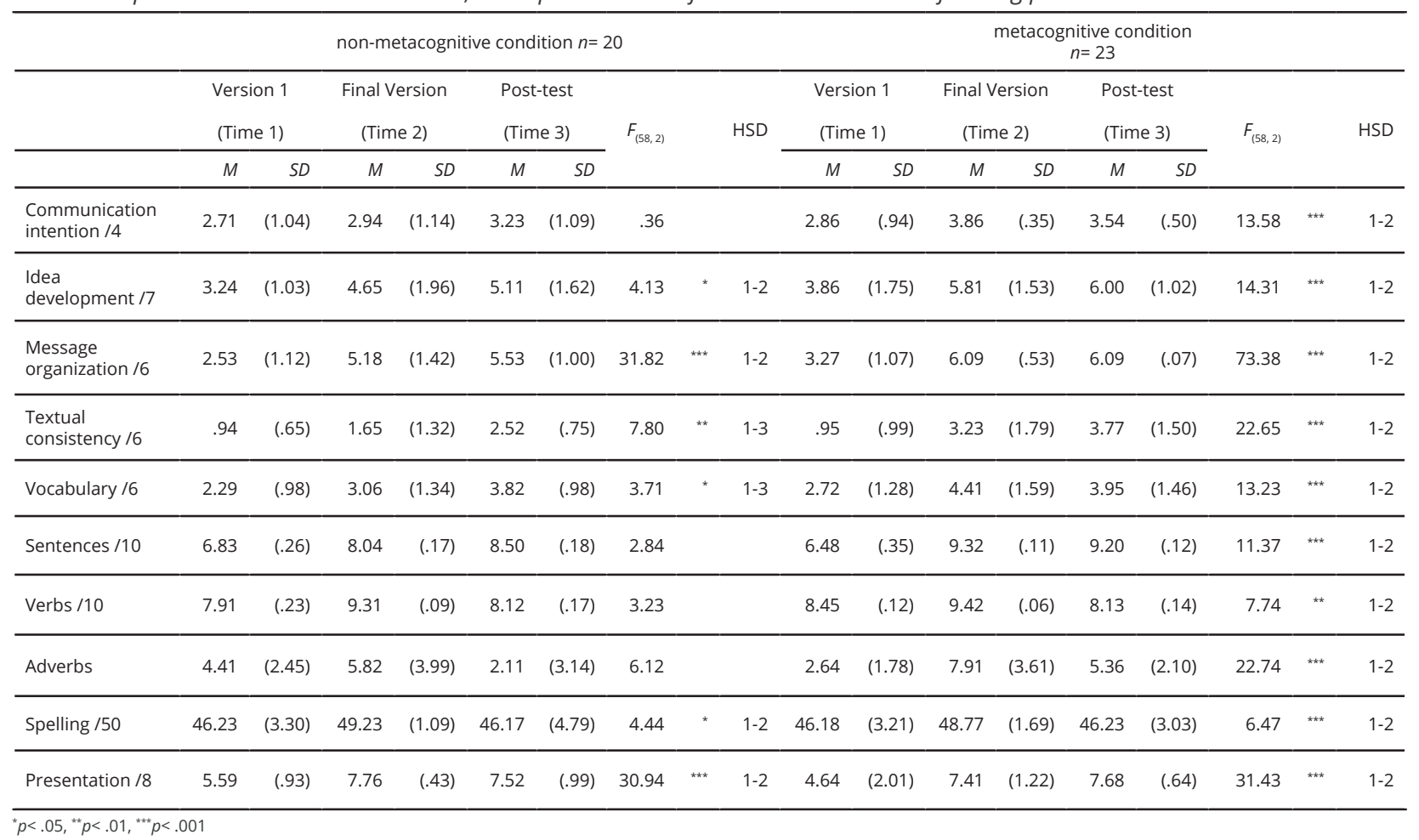

First, there were some significant improvements in both classes: in idea development, message organization, textual consistency, vocabulary, spelling and text presentation. This can be traced back to the effects of the instructional method. Indeed, the support provided by the teacher and the interactions between peers allowed these improvements to take place. This has already been shown in other studies (Authors, 2017, 2018a). Moreover, for these elements, there was no significant difference between time 2 (final version) and time 3 (post-test). This means that learning was stabilized and transferred by the pupils.

For four of the significant elements in the two conditions, the post-hoc test carried out showed that the significant improvement occurred between time 1 and time 2. That is to say, the progress was between the first and final versions produced during the learning process. In both classes, therefore, the pupils therefore progressed within the planned learning time. 
This was true for idea development, the organization of the message, the spelling and the presentation of the text.

For idea development, for the non-metacognitive condition, the mean was $3.24(S D=1.03)$ at time 1 and $4.65(S D=1.96)$ at time $2, F_{(58,2)}=4.13, p<.05$. In the metacognitive condition, the mean was $3.86(S D=1.75)$ at time 1 and $5.81(S D=1.53)$ at time $2, F_{(67,2)}=14.31, p<.001$. The mean of message organization for the non-metacognitive condition went from $2.53(S D=1.12)$ at time 1 to $5.18(S D=1.42)$ at time $2, F_{(58,}$ 2) $=31.82, p<.001$. In the metacognitive condition, the mean went from $3.27(S D=1.07)$ at time 1 to $6.09(S D=.53)$ at time $2, F_{(67.2)}=73.38, p<.001$. For spelling, the average went from $46.23(S D=3.3 .0)$ at time 1 to $49.23(S D=1.09)$ at time $2, F_{(58}$ ${ }_{2)}=4.44, p<.05$ for the non-metacognitive condition. It went from $46.18(S D=3.21)$ at time 1 to $48.77(S D=1.69)$ at time $2, F_{(67,2)}=6.47, p<.001$ for the metacognitive condition. And for presentation, the average went from $5.59(S D=.93)$ at time 1 to $7.76(S D=.43)$ at time $2, F_{(58,2)}=30.94, p<.001$ for the non-metacognitive condition. The mean score for presentation improved from $4.64(S D=2.01)$ at time 1 to $7.41(S D=$ 1.22) at time $2, F_{(67,2)}=31.43, p<.001$ for the metacognitive condition.

A different pattern was seen over time in the two conditions for two significant elements: textual consistency and vocabulary. In the non-metacognitive condition, the significant difference in the scores for these two elements was between time 1 and time 3. Textual consistency showed a mean of .94 $(S D=.65)$ at time 1 and $2.52(S D=7.80)$ at time $3, F_{(58,2)}=7.80$, $p<.05$. For vocabulary, the average went from $2.29(S D=.98)$ at time 1 to $3.82(S D=3.71)$ at time $3, F_{(58.2)}=3.71, p<.05$. For the metacognitive condition, the significant improvements for these two elements were between times 1 and 2. For textual consistency, the mean was $.95(S D=.99)$ at time 1 to $3.23(S D=1.79)$ at time $2, F_{(67,2)}=22.65, p<.001$. For vocabulary, the average went from $2.72(S D=1.28)$ at time 1 to $4.41(S D=1.59)$ at time $2, F_{(67,2)}=13.23, p<.001$. Here again the progress was during the dedicated learning process, between the first and final version of the text. These observations lead us to conclude that in the non-metacognitive condition the students needed more time to show progress on these elements.

Secondly, in the metacognitive condition, all elements showed significant improvement. Indeed, four elements showed significant improvements that were not present in the non-metacognitive condition. This progress was significant between times 1 and 2, with no differences between times 2 and 3, which means, once again, that the learning had already occurred and was transferred by the students. Thus, for students in the metacognitive condition, mean scores for communication intention went from $2.86(S D=.94)$ at time 1 to $3.86(S D=.35)$ at time $2, F_{(67.2)}=13.58 ; p<0.001$. For sentence construction, the average went from $6.48(S D=$ $.35)$ at time 1 to $9.32(S D=.11)$ at time $2, F_{(67,2)}=11.37, p<$ 0.005 . For verbs, the student results were $8.45(S D=.12)$ at time 1 and $9.42(S D=.06)$ at time $2, F_{(67,2)}=7.74, p<0.001$. And for adverbs, the mean went from $2.64(S D=1.78)$ at time 1 to $7.91(S D=3.61)$ at time $2, F_{(67,2)}=22.74, p<0.001$.

Three of the four elements that showed significant improvement for students in the metacognitive condition were those that were the subject of specific time spent working with the teacher. Indeed, communication intention was worked on by answering a series of questions (who is being written to, why, etc.) and the learning and production objectives were largely reformulated. In addition, adverbs and verbs were given special support. Students were given specific activities to work on for the present subjunctive and adverbs. These two skills were necessary for the production of a book review. Moreover, these results lead us to believe that the metacognitive mediations allowed students to better consolidate their learning, and that this allowed them to better reuse that learning in their final version.

Third, the t-tests carried out to compare post-test scores (time 3) showed three elements with significant differences between conditions (see Table 5). Indeed, for textual consistency the mean score on the post-test was $2.52(S D=.75)$ in the non-metacognitive condition and $3.77(S D=1.50)$ in the metacognitive condition, $t_{(41)}=2.92, p<.01$. For sentence construction, the average on the post-test was $8.50(S D=.18)$ in the non-metacognitive condition and $9.20(S D=.12)$ in the metacognitive condition, $t_{(11)}=2.73, p<.01$. And for adverbs, the score was $2.11(S D=3.14)$ in the non-metacognitive condition and $5.36(S D=2.10)$ in the metacognitive condition, $t_{(41)}=6.21, p<.001$.

\section{How do students respond to metacognitive questions?}

We were interested in explaining the progress made by the students in the metacognitive condition, presented above. This guided our content analysis. Why did these students improve more in constructing correct sentences and in using adverbs? These two aspects first caught our attention because they emerged from the comparison of the two classes during the process (Times 1-2 and 3), but also from the comparison of the two groups on the post-test (Time 3). Several aspects related to the improvement for these two elements emerged from the students' responses. They are highlighted below, and illustrated by emblematic verbatim statements (all from students in the metacognitive condition).

Table 5. Descriptive statistics and comparison of post-test scores for elements of writing skills per condition

\begin{tabular}{|c|c|c|c|c|c|c|}
\hline & \multicolumn{2}{|c|}{$\begin{array}{c}\text { non-metacognitive con- } \\
\text { dition } \\
n=20\end{array}$} & \multicolumn{2}{|c|}{$\begin{array}{l}\text { metacognitive condition } \\
\qquad n=23\end{array}$} & \multirow[t]{2}{*}{$t_{(41)}$} & \multirow[t]{2}{*}{$p$} \\
\hline & M & $S D$ & M & $S D$ & & \\
\hline Communication intention /4 & 3.23 & $(1.09)$ & 3.54 & (.50) & 1.18 & .246 \\
\hline Idea development /7 & 5.11 & (1.62) & 6.00 & $(1.02)$ & 1.93 & .061 \\
\hline Message organization /6 & 5.53 & $(1.00)$ & 6.09 & $(.07)$ & 1.77 & .086 \\
\hline Textual consistency /6 & 2.52 & (.75) & 3.77 & $(1.50)$ & 2.92 & .006 ** \\
\hline Vocabulary /6 & 3.82 & (.98) & 3.95 & (1.46) & .30 & .762 \\
\hline Sentence construction /10 & 8.50 & $(.18)$ & 9.20 & (.12) & 2.73 & $.009 * *$ \\
\hline Verbs /10 & 8.12 & $(.17)$ & 8.13 & (.14) & -1.67 & .098 \\
\hline Adverbs & 2.11 & (3.14) & 5.36 & (2.10) & 6.21 & $.000 * * *$ \\
\hline Spelling /50 & 46.17 & (4.79) & 46.23 & (3.03) & .04 & .968 \\
\hline Presentation /8 & 7.52 & (.99) & 7.68 & (.64) & .74 & .463 \\
\hline
\end{tabular}


Comments related to sentence improvement and the use of adverbs appeared in many of the students' responses. First, these aspects were mentioned when students were planning. They explicitly said that they wanted to write more correct sentences. They also verbalized the fact that it is important to add adverbs (here it is important to remember that the scaffolding related to adverbs was presented between versions 3 and 4). And they justified why.

I'll make my sentences more precise. I will read them again and formulate them better. To make you want to read it more. (SI, before V2)

I will try to add some more adverbs to clarify more...to give information in my review (VOL, before V4).

I'm going to add some adverbs. It might make the text more precise. It will be more precise. More pleasant to read too. (VA, before v4)

Secondly, when students took stock after writing, they still mentioned these aspects. They talked about their evolving text because there was more text, because the sentences were more understandable, better written. They also noted that the text was of better quality because they used adverbs So, it seems that these aspects were used as important criteria when students evaluated their written products.

I wrote more things. I'm happy. My text is getting longer. I have inserted more information. (VO, after V2)

This second version is much more spaced out. Much more beautiful. It still makes you want to read it. My sentences are easier to understand. They're better written. I had time to correct. (SI, after V3)

I got better... we did some stuff to uh... to uh... to uh... to learn how to improve it, how to write better... with better words... uh... with lots of adverbs. (Ni, after V4)

I've added details. And now it's better and I added more details thanks to the adverbs. (FA, after V4)

Thirdly, these elements also appeared when students were questioned at the end of the process, when they had to explain what they would keep if they did this writing task again. The students expressed that they would be careful to construct correct and understandable sentences. They also said that they would use adverbs, justifying why. Note also that the students talked in addition about the other instructional activity, in which the text structure was worked on. This shows that the scaffolding provided by the teacher was used as a reference point when considering a new writing task. In the end, it seems that the students here used what they had been working on in the "adverb" scaffolding to answer metacognitive questions. There were also mentions of the other types of scaffolding, but they were less frequent. Thus, while many answers dealt with text structure, few related only to verbs.

What helped me the most was the structure and the adverbs. To do it again, I'll pay attention to the structure. By making small paragraphs and notes. I'll make sentences that you can understand. And also the adverbs, because that way it's more precise. (NI, after Final version)

I notice that... there's... uh... there's a lot more information,.. and... and... and ... and uh . the texts are better written. Because we saw how to do the structure. (SU, after V2)

Fourth, in their responses, students also referred to the advice they received. They still used the fact that it is important to write correct sentences, and that adverbs are important. They also expressed the need to add tense connectors and avoid repetition. These aspects were related to the third aspect that was significant in the post-test: textual consistency.
I'll rewrite it. I've been told to watch out for repetitions. I'll try. (LO, before V3)

I have to add connectors to link the information. (FA, before V3)

Fifth, an additional aspect to note is that students talked about the differences they saw between their versions. They expressed satisfaction with the results, and said they are proud of what they produced. They mentioned that they see what they have achieved as progress. Several examples above already showed this. These aspects are directly related to feelings of competence. This seems to be important, especially in the context of writing activities, because this awareness leads students to strengthen their relationship with writing.

Yes, I'm very satisfied. Since I started critiquing, it has improved a lot. I've written a lot more, and there are paragraphs. There are more ideas. I think my text is much better now (NO, after Final version).

The students also mentioned that they had learned things. This is interesting in the sense that they made connections between what they learned and what they produced. In this way, they explained that the aspects they worked on were directly useful in the following revisions. This can be linked to motivational theories that take into account the task value that students assign (Eccles \& Wiegfield, 2002).

We've learned a lot... it's helped us improve our review (FA, after Final version).

\section{Conclusion}

In this study, we wanted to see the effects of metacognitive mediations integrated into a writing instruction program. This writing instruction program incorporates the various principles of effective writing instruction: goal setting, peer support, teacher feedback and instruction in writing strategies (Koster et al., 2015; van Weijen \& Janssen, 2018). We worked with two groups who went through the same learning sessions in this instructional program for four weeks. One group also participated in metacognitive mediations before, during and after the periods of writing. The other did not.

Our results show that students in both conditions made significant progress for the following elements: idea development, general organization of the text, textual consistency, vocabulary, spelling, and text presentation. We attributed these improvements to the instructional program and its effective practices.

On the other hand, in the metacognitive condition, students made more significant progress. They also made progress in the following elements: communicative intention, correct sentence construction, subject-verb agreement, and use of adverbs. On the other hand, the comparison of the post-tests of the two groups shows that in the metacognitive condition, the results were more striking. This links with the results of Graham, Harris, and Mason (2005), Escorcia and Fenouillet (2011) and Cer (2019): metacognition improved writing skills. In short, the metacognitive condition allowed students to make better progress and achieve better writing products.

An interesting aspect to note is certainly what happened with regard to adverbs for students in the metacognitive condition. This aspect improved significantly between version 1 and the final version, therefore during the instructional program. It also showed significant improvement on the post-test. The adverbs were the subject of instructional scaffolding. Metacognitive mediation would therefore have enabled the students to better anchor this knowledge, and to better see the links it could have with writing. In fact, they made extensive mention of this aspect in their metacognitive responses, whether with regard to planning their writing or evaluating it. Metacognition 
would then have been used here to transfer this knowledge. Of course, this remains to be verified more widely.

Qualitative analysis of student responses also showed that students in the metacognitive condition talked about their progress. This may lead to the conclusion that they see themselves as becoming more proficient as they progress through the writing process. We had already shown this (Colognesi et al., 2019) for 11-12-year-old students in history class who were asked to write summaries. This aspect seems to be important for the relationship that students may have with writing. This also connects with other work (Colognesi \& Lucchini, 2016b; Niwese \& Bazile, 2014) that has highlighted the importance of the metascriptural dimension in the relationship with the written word.

Several limitations and perspectives need to be identified. First of all, our sample is a significant limitation. Its size (43 participants) does not allow us to generalize the results. We intend to replicate this experiment on a larger scale to confirm our findings. In particular, we intend to investigate the question of the transfer of grammatical learning.

Second, we did not measure students' metacognitive knowledge and strategies. We do not know, therefore, whether these changed for students in the metacognitive condition. We have anticipated this in our next study, following the recommendations of Escorcia and Fenouillet $(2011,2018)$ and Jacob, Dörrenbächer and Perels (2019). Moreover, in our experiment, metacognitive activation occurred only orally. Thus, the students had to respond directly to the mediating questions without being prepared for them. However, we know that metacognition requires habit (Büchel, 2015). It seems that several questions arise here: what are the students' initial capacities to answer metacognitive questions? what would be useful interventions to help them deal with these kinds of questions? And what would be the results if the students were asked to respond in writing?

Finally, while the teacher had received training in the instructional program, he did not receive specific training in metacognition. It should be noted, however, that the majority of researcher interactions with the teacher to address questions were in this area. This reinforces the idea that teachers do not feel secure in implementing metacognition-related instruction in their classrooms (Depaepe et al., 2015; Vlassis et al., 2014). Thus, it seems, and our results encourage this, that metacognition needs to take its place in teacher education programs. Some questions then arise, such as: What knowledge and beliefs do future teachers have about metacognition? What are the factors that can help them implement metacognition-related instruction in their teaching practices? This is also an aspect that could be included in teachers' course materials. In this sense, it could help teachers to prepare their materials (Coppe et al., 2018), while including metacognition in the different moments of learning.

At the very least, the contribution of this study is to have isolated the effect of just adding metacognitive questions within an already effective instructional program. And that the time it took to do this did not hinder students from progressing as much/better than those who were able to spend all that time on working. Another interesting question is not just that they answered the questions orally, but that they discussed some of them with their peers in groups. That form of interaction could have made a difference also. This is something that remains to be investigated.

\section{References}

Andrade, H. (1999). Student self-assessment: At the intersection of metacognition and authentic assessment (ED 431 030). Retrieved from https://files.eric.ed.gov/ fulltext/ED431030.pdf

Ben-David, A., \& Orion, N. (2013). Teachers' voices on integrating metacognition into science education. International Journal of Science Education, 35(18), 3161 3193. DOI: $10.1080 / 09500693.2012 .697208$

Braund, H., \& Soleas, E. (2019). The struggle is real: Metacognitive conceptualizations, actions, and beliefs of pre-service and in-service teachers. In J. Mena, A. Garcia-Calcarel, \& F. Garcia-PeNalvo, (Eds.), Teachers' professional development in global contexts (pp. 105124). Brill-Sense.

Brown, A. L. (1987). Metacognition, executive control, self-regulation, and other more mysterious mechanisms. In F. E. Weinert \& R. H. Kluwe (Eds.), Metacognition, motivation, and understanding (pp. 65-116). Hillsdale, NJ: Erlbaum.

Brown, A. L., \& DeLoache, J. S. (1978). Skills, plans, and self-regulation. In R. S. Siegler (Ed.), Children's thinking: What develops? (pp. 3-35). Erlbaum.

Büchel, F. P. (2015). De la métacognition à l'éducabilité cognitive [From metacognition to cognitive educability]. In F. P. Büchel (Ed.), L'education cognitive, le développement de la capacité d'apprentissage et son évaluation [Cognitive education, development of learning capacity and its evaluation; pp. 9-44]. Lausanne, Suisse: Delachaux et Niestlé.

Cer, E. (2019). The instruction of writing strategies: The effect of the metacognitive strategy on the writing skills of pupils in secondary education. Sage Open.

Creswell, J., \& Plano Clark, V. (2007). Designing and conducting mixed methods research. Thousand Oaks, CA: Sage.

Colognesi, S., \& Lucchini, S. (2016a). Mise à l'épreuve de deux dispositifs pour développer l'écriture en milieu scolaire [Testing of two instructional programs to develop writing in schools]. Enfance, 2016(2), 193215. https://doi.org/10.4074/S0013754516002032

Colognesi, S., \& Lucchini, S. (2016b). Le rapport à l'écrit des élèves : focalisation sur la dimension métascripturale [Students' relationship to writing: focusing on the metascriptural dimension]. Nouveaux cahiers de la recherche en éducation, 19(2), 33-52. https://doi. org/10.7202/1042848ar

Colognesi, S., \& Deschepper, C. (2018). La relecture collaborative comme levier de réécriture et de soutien aux corrections des textes [Collaborative proofreading as a lever for rewriting and support for text corrections]. Le français aujourd'hui, 203(4), 63-72. doi:10.3917/Ifa.203.0063.

Colognesi, S., \& Lucchini, S. (2018a). Enseigner l'écriture : l'impact des étayages et des interactions entre pairs sur le développement de la compétence scripturale [Teaching Writing: The Impact of scaffolding and peer interaction on the development of writing skills]. Canadian Journal of Education, 41(1), 514- 540. 
Colognesi, S., \& Lucchini, S. (2018b). Aider les élèves à améliorer leurs écrits : les effets d'un étayage spécifique sur la superstructure textuelle [Helping students improve their writing: The effects of a specific activity on text superstructure]. Repères, 57(2018), 143-162. https:// doi.org/10.4000/reperes.1540

Colognesi, S., Hanin, V., Still, A., \& Van Nieuwenhoven, C. (2019). The Impact of Metacognitive Mediation on 12-Year-Old Students' Self-Efficacy Beliefs for Performing Complex Tasks. International Electronic Journal Of Elementary Education, 12(2), 127-136. Retrieved from https://www. iejee.com/index.php/IEJEE/article/view/982

Colognesi, S. \& Niwese, M. (2020). Do effective practices for teaching writing change students' relationship to writing? Exploratory study with students aged 10-12 years. L1-Educational Studies in Language and Literature, 20, 1-25. https://doi.org/10.17239/L1ESLL-2020.20.01.05

Coppe, T., März, V., Decuypere, M., Springuel, F. \& Colognesi, S. (2018). Ouvrir la boite noire du travail de préparation de l'enseignant : essai de modélisation et d'illustration autour du choix et de l'évolution d'un document support de cours, [Opening the black box of course preparation: presenting a model and illustration of the choice and development of course material]. Revue française de pédagogie, 204(3), 17-31.

Dabène, M. (1991). Un modèle didactique de la compétence scripturale [A didactic model of competence in writing]. Repères, 41, 9-22.

Depaepe, F., De Corte, E., \& Verschaffel, L. (2010). Teachers' approaches towards word problem solving: elaborating or restricting the problem context. Teaching and Teacher Education, 26(2), 152-160.

Depaepe, F., De Corte, E., \& Verschaffel, L. (2015). Students' non-realistic mathematical modeling as drawback of teachers' beliefs about and approaches to word problem solving. In B. Roesken-Winter (Ed.), From beliefs to dynamic affect systems in mathematics education (pp. 137-156). Springer International Publishing.

Desoete, A. (2017). Mathematics and metacognition in adolescents and adults with learning disabilities. International Electronic Journal Of Elementary Education, 2(1), 82-100. Retrieved from https://www.iejee.com/index.php/IEJEE/article/view/259

Desoete, A., \& Özsoy, G. (2009). Introduction: Metacognition, more than the Loch Ness monster? International Electronic Journal of Elementary Education, 2(1), 1-6. Retrieved from https://www.iejee.com/index.php/IEJEE/ article/view/266

Doly, A-M. (1997). Métacognition et médiation à l'école [Metacognition and mediation at school]. In M. Grangeat (Ed.) La métacognition, une aide au travail des élèves [Metacognition as an aid to student work; pp. 17-61]. ESF.

Dörr, L., \& Perels, F. (2019). Improving Metacognitive Abilities as an Important Prerequisite for Self-regulated Learning in Preschool Children. International Electronic Journal Of Elementary Education, 11(5), 449-459. Retrieved from https://www.iejee.com/index.php/IEJEE/article/ view/838

Doudin, P. A., Martin, D., \& Albanese, O. (1999). Métacognition et éducation [Metacognition and education]. Berlin : Peter Lang S.A.
Eccles, J., \& Wigfield, A. (2002). Motivational beliefs, values, and goals. Annual Review of Psychology, 53, 109-132.

Efklides A. (2006). Metacognition and affect: What can metacognitive experiences tell us about the learning process? Educational Research Review, 1, 3-14. doi: 10.1016/j.edurev.2005.11.001

Efklides A. (2008). Metacognition: Defining its facets and levels of functioning in relation to self-regulation and co-regulation. European Psychologist, 13(4), 277-287. doi: 10.1027/1016-9040.13.4.277

Escorcia, D., \& Fenouillet, F. (2011). Quel rôle de la métacognition dans les performances en écriture?: analyse de la situation d'étudiants en sciences humaines et sociales [What role does metacognition play in writing performance?: analysis of the situation of students in the humanities and social sciences]. Revue Canadienne de l'Éducation, 34(2), 53-76.

Escorcia, D., \& Fenouillet, F. (2018). Connaissances métacognitives et stratégies d'autorégulation impliquées dans la révision de textes : construction et validation d'un instrument autorapporté [Metacognitive knowledge and self-regulatory strategies involved in the revision of texts: construction and validation of a self-report instrument]. Mesure et Évaluation en Éducation, 41(2), 1-36. https://doi.org/10.7202/1059171ar

Flavell, J. H. (1976). Metacognitive aspects of problem-solving. In L. B. Resnick (Ed.), The nature of intelligence (pp. 231235). Hillsdale, NJ: Erlbaum.

Focant, J. (2004). Stratégies d'autorégulation d'élèves de cinquième primaire en situation de résolution de problèmes arithmétiques [Self-regulatory strategies for Primary 5 students in arithmetic problem-solving situations; unpublished doctoral thesis]. Louvain-laNeuve, Université Catholique de Louvain.

Focant, J., Grégoire, J., \& Desoete. (2006). Goal-setting, planning and control strategies and arithmetical problem solving at grade 5. In A. Desoete \& M. Veenman (Eds.), Metacognition in mathematics education (pp. 51-72). Netherlands: Leiden University.

Fox M. C., Ericsson K. A., Best R. (2011). Do procedures for verbal reporting of thinking have to be reactive? A meta-analysis and recommendations for best reporting methods. Psychol. Bull., 137, 316-344.

Gagnière, L. (2010). Comment inciter les régulations métacognitives pour favoriser la résolution de problèmes mal structurés? [How to encourage metacognitive regulation to promote the resolution of poorly structured problems; unpublished doctoral thesis]. Université de Genève, Genève.

Graham, S., Harris, K., \& Mason, L. (2005). Improving the writing performance, knowledge, and self-efficacy of struggling young writers: The effects of self-regulated strategy development. Contemporary Educational Psychology, 30(2), 207-241. https://doi.org/10.1016/j. cedpsych.2004.08.001

Jacob, L., Dörrenbächer, S., \& Perels, F. (2019). A Pilot study of the Online Assessment of Self-Regulated Learning in Preschool Children. International Electronic Journal Of Elementary Education, 12(2), 115-126. Retrieved from https://www.iejee.com/index.php/IEJEE/article/ view/981 
Hacker, D. J. (1998). Definitions and empirical foundations. In D. J. Hacker, J. Dunlosky, \& A. C. Graesser (Eds.). Metacognition in educational theory and practice (pp. 1-23). Mahwah, NJ : Erlbaum.

Hanin, V. (2018). Une approche tridimensionnelle de la résolution de problèmes mathématiques chez les élèves en fin d'enseignement primaire? [A three-dimensional approach to mathematical problem solving in late primary school students; unpublished doctoral thesis]. Université Catholique de Louvain, Louvain-la-Neuve.

Hanin, V., \& Van Nieuwenhoven, C. (2018). Évaluation d'un dispositif d'enseignement- apprentissage en résolution de problèmes mathématiques: Évolution des comportements cognitifs, métacognitifs, motivationnels et émotionnels d'un résolveur novice et expert. [Evaluation of a teaching-learning device in mathematical problem solving: Evolution of the cognitive, metacognitive, motivational and emotional behaviours of a novice and expert problem solver]. Évaluer. Journal International de Recherche en Éducation et Formation, 4(1), 37-66.

Harris, K. R., \& Graham, S. (1996). Making the writing process work: Strategies for composition and self-regulation. Cambridge, MA: Brookline.

Hattie, J. (2009). Visible learning: A synthesis of over 800 meta-analyses related to achievement. London: Routledge.

Hayes, J., \& Flower, L. (1980). Identifying the organization of writing processes. In L. Gregg \& E. Steinberg (Eds.), Cognitive processes in writing (pp. 3-30). Hillsdale, NJ: Erlbaum.

Houart, M. (2017). L'apprentissage autorégulé: Quand la métacognition orchestre motivation, volition et cognition. Un modèle pour l'action pédagogique qui vise à rendre les étudiants plus autonomes [Self-regulated learning: When metacognition orchestrates motivation, volition and cognition. A model for pedagogical action that aims to make students more autonomous]. Revue Internationale de Pédagogie de I'Enseignement Supérieur (RIPES), 2(33).

Kellogg, R. T. (2008). Training writing skills: A cognitive developmental perspective. Journal of Writing Research, $1,1-26$.

Kim, M. M. J. (2016). Writing about writing: Qualities of metacognitive L2 writing reflections. Second Language Studies, 34(2), 1-54.

Ko, J., Sammons, P., \& Bakkum, L. (2014). Effective teaching: A review of research and evidence. England: CfBT Education Trust.

Koster, M., Tribushinina, E., De Jong, P. F., \& van den Bergh, H. (2015). Teaching children to write: A meta-analysis of writing intervention research. Journal of Writing Research, 7(2), 299-324.

L'Écuyer, R. (1990). Méthodologie de l'analyse développementale des contenus. Méthode GPS et concept de soi [Methodology of developmental content analysis. GPS method and self-concept]. Québec, Canada : Presses de l'Université du Québec.
Lester, F. K, Garofalo, J., \& Kroll, D. (1989). The role of metacognition in mathematical problem solving: a study of two grade seven classes. Bloomington IN: University of Indiana Mathematics Education Development Center.

Lord, M.-A. (2009). Composantes prises en compte dans l'évaluation de la compétence scripturale des élèves par des enseignants d'histoire du secondaire au Québec [Components taken into account in the assessment of students' writing competence by secondary school history teachers in Quebec]. Revue Canadienne des Jeunes Chercheures et Chercheurs en Éducation, 2(1), 1-9.

Lu, W. J. (2006). Relationship between metacognitive strategies and English writing. Foreign Languages and Their Teaching, 9, 25-27.

Mekala, S., Shabitha, M. P., \& Ponmani, M. (2016). The role of metacognitive strategies in second language writing. GSTF Journal on Education, 4, 11-19.

Miles, M. B., \& Huberman, A. M. (2014). Qualitative data analysis: An expanded source book (3rd ed.). London, England: Sage.

Mitchum, A. L., Kelley, C. M., \& Fox, M. C. (2016). When asking the question changes the ultimate answer: Metamemory judgments change memory. Journal of Experimental Psychology - General, 145, 200-219. doi: 10.1037/a0039923

Niwese, M., \& Bazile, S. (2014). L'atelier d'écriture comme dispositif de diagnostic et de développement de la compétence scripturale : du centre de formations d'adultes à la classe [The writing workshop as a diagnostic and developmental device for writing competence: from the adult training center to the classroom]. Pratiques, 161-162. http://pratiques.revues. org/2063

Nelson, T. O., \& Dunlosky, J. (1991). When people's judgments of learning (JOLs) are extremely accurate at predicting subsequent recall: The "delayed-JOL effect." Psychological Science, 2(4), 267-270. https://doi. org/10.1111/j.1467-9280.1991.tb00147.x

Noël, B. (1997). La métacognition [Metacognition]. Bruxelles: De Boeck.

Özsoy, G. (2011). An investigation of the relationship between metacognition and mathematics achievement. Asia Pacific Education Review, 12(2), 227-235.

Özsoy, G., \& Ataman, A. (2009). The effect of metacognitive strategy training on mathematical problem solving achievement. International Electronic Journal of Elementary Education, 1(2), 68-83.

Perfect, T. J., \& Schwartz, B. L. (2002). Applied metacognition (1st ed.). Cambridge, UK: Cambridge University Press.

Portelance, L. (1999). Enseigner pour développer la compétence métacognitive : analyse des liens entre des pratiques et les intentions qui les sous-tendent chez des enseignants de l'ordre secondaire [Teaching for development of metacognitive competence: Analyzing the links between practices and underlying intentions in secondary school teachers ; unpublished doctoral thesis]. Université de Montréal, Montréal. 
Ramet, A. (2007). Creative writing: How to unlock your imagination, develop your writing skills and get published (6th ed.). Oxford, UK: How to Books.

Schraw, G. (1998). Promoting general metacognitive awareness. Instructional Science, 26, 113-125.

Stankov, L., \& Lee, J. (2008). Confidence and cognitive test performance. Journal of Educational Psychology, 100(4), 961-976. https://doi.org/10.1037/a0012546

Sternberg, R. J. (1998). Metacognition, abilities and developing expertise: What makes an expert student? Instructional Science, 26, 127- 140.

van Weijen, D., \& Janssen, T. (2018). High-quality writing instruction in Dutch primary education. A framework for national assessment. L1-Educational Studies in Language and Literature, 18, 1-41. https://doi.org/10.17239/ L1ESLL- 2018.18.03.03

Veenman, M. (2005). The assessment of metacognitive skills: What can be learned from multi-method designs? In C. Artelt \& B. Moschner (Eds.), Lernstrategien und Metakognition: Implikationen für Forschung und Praxis (pp. 75-97). Berlin: Waxmann.

Veenman, M., Van Hout-Wolters, B. H. A. M., \& Afflerbach, P. (2006). Metacognition and learning: conceptual and methodological considerations. Metacognition and Learning, 1, 3-14.

Veenman, M. (2012). Metacognition in science education: Definitions, constituents, and their intricate relation with cognition. In A. Zohar and Y-J. Dori (Eds.), Metacognition in science education: Trends in current research (pp. 21. 36). London, UK : Springer.

Vlassis, J., Mancuso, G., \& Poncelet, D. (2014). Le rôle des problèmes dans l'enseignement des mathématiques: analyse des croyances d'enseignants du primaire [The Role of Problems in Mathematics Education: An Analysis of Primary Teachers' Beliefs]. Les Cahiers des Sciences de l'Education, 36, 143-175.

Wilson, N. S., \& Bai, H. (2010). The relationships and impact of teachers' metacognitive knowledge and pedagogical understandings of metacognition. Metacognition and Learning, 5(3), 269-189.

Yanyan, Z. (2010). Investigating the role of metacognitive knowledge in English Writing 1. HKBU Papers in Applied Language Studies, 14, 25-46.

Yeung, N., \& Summerfield, C. (2014). Shared mechanisms for confidence judgements and error detection in human decision making. In S. M. Fleming \& C. D. Frith (Eds.), The cognitive neuroscience of metacognition (pp. 147167). New York, NY: Springer-Verlag.

Zimmerman, B. J. (1995). Dimensions of academic self-regulation: A conceptual framework for education. In B. J. Zimmerman \& D. H. Schunk (Eds.), Self-regulation of learning and performance (pp. 3-24). Hillsdale, NJ: Erlbaum.

Zimmerman, B. J., \& Bandura, A. (1994). Impact of self-regulatory influences on writing course attainment. American Educational Research Journal, 31, 845-862.
Zimmerman, B, Bonner, S. \& Kovach, R. (2000). Des apprenants autonomes. Autorégulation des apprentissages [Independent learners. Self-regulation of learning]. Bruxelles, Belgique: De Boeck.

Zimmerman, B. J., \& Kitsantas, A. (2007). A writer's discipline: The development of self-regulatory skill. In P. Boscolo \& S. Hidi (Eds.), Writing and motivation (pp. 51-69). Oxford, UK: Elsevier.

Zimmerman, B. J., \& Risemberg, R. (1997). Becoming a self-regulated writer: A social cognitive perspective. Contemporary Educational Psychology, 22, 73-101. 